\title{
THE APPLIED ISSUES OF HABITATS FRAGMENTATION MITIGATION FOR THE PROJECTS OF INFRASTRUCTURE DEVELOPMENT
}

\begin{abstract}
A transport network is an artificial component of the human environment, which causes a range of negative impacts on other living organisms, including violation of animal habitats integrity. Ability to move in search of food, shelter or mating, is negatively limited by obstacles that isolate the habitat. The term "habitat fragmentation" includes breaking habitat into several smaller patches, reduction in the total area of the habitat, decrease of the interior/edge ratio, and isolation of one habitat fragment from others. Consequently, roads divide habitats and create barriers that impede wildlife mobility, increasing instances of wildlife-vehicle collisions, which put both people and non-human animals at risk; landscape fragmentation can also result in genetic isolation, putting some species of wildlife at long term risk of extinction. Secondary effects from infrastructure development are further emergence of human settlements or industrial development, which put people and their activity closer to wildlife. In order to reduce the negative impacts of roads, the measures that directly reduce fragmentation by providing links between habitats, namely wildlife crossing structures or fauna passages should be implemented. The pilot area at the highway M-03 from Poltava to Kharkiv between 341 and $472 \mathrm{~km}$ planned for reconstruction under the World Bank project was analyzed based on spatial ecosystem approach to define the points of increased concern for the protection of habitats. Mitigation measures, in particular fauna passages, are necessary as the given road bisects important elements of eco-network: Galytsko-Slobozhansky natural latitudinal corridor and Vorskla regional ecocorridor. Five sites were chosen on the territory to provide wildlife mobility improvement with the help of such crossing structures, as landscape bridge, river crossing, joint-use underpass, underpass for small- and medium-sized animals, and multi-use overpass. The selection of the most appropriate type of fauna passage was based on the analysis of landscape structure, type of habitats affected and target species (their living needs, behaviour and preferred moving media). The suggested scheme of wildlife crossings is provided with recommendations on the design of the offered structures, their dimensions, construction materials and elements, as well as details about model target species and their nature conservation status. The cost of the project is supposed to be acceptable as it basically involves transformation of the existing infrastructure elements.
\end{abstract}

Keywords: biodiversity conservation; ecological network; ecological corridors; wildlife mobility; wildlife crossing.

Introduction. The operation of the transport network generates significant, mostly negative, effects on the components of the environment, including division of habitats and hydrological features. The issues of the interactions between roads and environment are covered by the new scientific discipline - road ecology, which has been initiated over 15 years ago by R. T. Forman (Forman et al., 2002). The effects of roads on wildlife populations have been the focus of many studies since then, but in Ukraine these issues haven't been paid much attention even considering active implementation of the state projects aimed at improvement of roads. So, there is a need to develop approaches for minimizing negative impacts on habitats for specific infrastructure development projects.

Effects of fragmentation on wildlife. For the stable survival of animal populations, each individual needs a sufficient place to move in order to get food, build shelter, reproduce or avoid seasonal changes of living conditions (Hunter, 1996). So, any obstacle, which prevents normal mobility of animals, literary breaks the habitat down into separate blocks, often inaccessible or dangerous to cross and this is the case for transport networks. Of course, human activity has begun to scatter natural ecosystems since the origination of agriculture, but the intensity of the fragmentation grew considerably in the industrial era (Damarad $\&$ Bekker, 2003).

Habitats separation may have primary and secondary effects. The direct impacts are obvious: loss of habitats or their parts; creation of interferences (barrier effect); bruising and injuring of fauna due to collisions with vehicle; disturbances of tranquility by noise and reduced quality of living conditions due to chemical pollution; change of road edges ecological functions and development of edge effect.

Influence of infrastructure is the most dramatic on the inner core of the habitat, as it has very specific flora and fauna, different from that at the border of the ecosystem, which is not isolated from the outside impacts and is normally made of common ubiquitous species. As a result, the area of the core's habitat loss is much larger than that which is occupied directly by the roadway due to the greater edge

\section{Інформація про авторів:}

Радомська Маргарита Мирославівна, канд. техн. наук, доцент, кафедра екологіï. Email: m.m.radomskaya@gmail.com

Журбас Катерина Вікторівна, магістр, фахівець відділу управління інноваційними проектами освіти.

Email: kzhurbas08@gmail.com

Цитування за ДстУ: Радомська М. М., Журбас К. В. The applied issues of habitats fragmentation mitigation for the projects of infrastructure development. Науковий вісник НЛтУ України. 2018, т. 28, № 6. С. 30-34.

Citation APA: Radomska, M. M., \& Zhurbas, K. V. (2018). The applied issues of habitats fragmentation mitigation for the projects of infrastructure development. Scientific Bulletin of UNFU, 28(6), 30-34. https://doi.org/10.15421/40280605 
effect along the road (Beier et al., 2007). The roads and edges in Europe cover the area of land from about $0.3 \%$ in Norway to over $5 \%$ in the Netherlands (Damarad \& Bekker, 2003). For Ukraine, this value is $0.29 \%$ (Kozak et al., 2013). Therefore, at regional or national levels, alienation of land under infrastructure is not a serious factor yet. However, at the local level, this inevitably leads to conflicts with other types of land use, primarily with conservation of nature.

The barrier effect of roads and railways is probably their greatest negative environmental impact (Bennett, 2004). Both physical and behavioral barriers affect the dynamics of the population and often threaten the survival of species. For most large mammals, transport infrastructure becomes an insurmountable physical barrier only if fences are created or if the traffic intensity is high (Table). However, fence near the passage can be used to provide safely of the fauna. For smaller animals, especially invertebrates, the road as such and its edges become a much more severe obstacle due to either the unfriendly environment, or to disturbing of tranquility.

Behavioral barriers appear as noise from traffic density and secondary development raise disturbance of animals and prevent their normal living activity along the road (Donovan, 1995). Other animals, such as small mammals and some forest birds, even avoid access to large open spaces (Reijnen et al., 1997). There is still an unexplored factor of illumination (attractive for some species and frightening for others) (Crooks, 2006).

Table. Dependence of barrier effect on traffic intensity (Damarad \& Bekker, 2003)

\begin{tabular}{|c|c|}
\hline $\begin{array}{c}\text { Traffic intensity } \\
\text { (density of vehicles) }\end{array}$ & \multicolumn{1}{|c|}{ Permeability for animals } \\
\hline $\begin{array}{c}\text { ess than } 1000 \text { vehic- } \\
\text { les per day }\end{array}$ & Permeable to most species of wildlife \\
\hline $\begin{array}{c}\text { from } 1000 \text { to } 4000 \\
\text { vehicles per day }\end{array}$ & $\begin{array}{l}\text { Permeable for some species, however, cer- } \\
\text { tain sensitive species avoid the intersection }\end{array}$ \\
\hline $\begin{array}{c}\text { from } 4,000 \text { to } 10,000 \\
\text { vehicles per day }\end{array}$ & $\begin{array}{l}\text { Strong barrier, noise and movement scare } \\
\text { away animals. Attempts to cross the road } \\
\text { lead to collisions with transport }\end{array}$ \\
\hline $\begin{array}{c}\text { more than } 10,000 \\
\text { vehicles per day }\end{array}$ & Impermeable to most species \\
\hline
\end{tabular}

Mortality is the most famous manifestation of the road traffic impact on wildlife and it is especially dangerous for the following animals (Beier et al., 2008): rare species with small local populations and extensive individual populated habitats, such as large carnivores; species, which have daily or seasonal migration movements between local settlements (for example, amphibians, deer); species, which have long seasonal migrations from summer to winter, moving around food spaces, such as elk and deer; large predator birds, like owls, which are attracted to the grassy roadside to hunt for small mammals and populations of singing birds that concentrate there.

However, with the increase in traffic intensity, the number of animal killing increases linearly, until the noise and movement of vehicles do not stop animals attempts to cross the road (Sawaya et al., 2013).

As for the influence of highways on the level of environment pollution it is covered by many research works, studying emissions from vehicles, spills of fuels and lubricants, de-icing and anti-icing agents' run-off from the road cover, etc. But it is also important to account changes of the topography and large-scale changes in hydrology: erosion and drainage of aquifers, change of water regime, and creation of dry or wet areas (Reijnen et al., 1997).

Ecofunctions of roadsides are also a widely discussed topic. They can be an important habitat for some species of wild animals, ensure the connectivity of the eco-network and function as corridors for longitudinal movement, but can also lead animals to places where their mortality increases, and they also serve as a medium for the spread of alien species (Benítez-López, 2010).

Secondary effects are further changes in land use, in particular, emergence of human settlements or industrial development at the newly accessed locations. As a result the level of people's access and disturbance increase: hunters and tourists gain access to the wildlife habitations of no concern (Fahrig \& Rytwinski, 2009). Finally, the disappearance of one specimen leads to transformations of other populations, initiating the process of ecosystem restructuring and succession chain reaction.

Principles of habitats protection and fragmentation mitigation. Measures for protecting wildlife along transport infrastructure and reduce habitat fragmentation can be divided into two groups:

- measures that directly reduce fragmentation by providing links between habitats destroyed by the infrastructure, for example, wildlife crossing structures;

- measures, aimed at improving road safety and reduction of the impact of traffic on animal populations by reducing traffic-related mortality.

In practice measures fulfill both functions but can also have an associated negative impact. For example, fences reduce the number of collisions between large mammals and cars, but at the same time they increase habitat fragmentation. Thus, fences can be regarded as a mitigation measure for fragmentation only in combination with fauna passages that compensate for their negative barrier effect.

The further distinction can be made regarding the objective of particular engineering measures. Fauna passages may be designed specifically for animals with human access prohibited. On the other hand, bridges, culverts or other structures built for people can be modified to increase the permeability of the infrastructure for animals. The selection of the most appropriate type of fauna passage requires consideration of the landscape, habitats affected and target species. Modifying engineering works is often the most appropriate and cheap way to reduce the barrier effect of existing roads and railway lines.

The characteristics of the pilot area. During 2010 2014 the World Bank supported the Government of Ukraine in implementation of the First and the Second Road and Safety Improvement Projects (RSIP I and RSIP II). Currently, the World Bank confirmed its interest to support the implementation of the Road Sector Development Project (RSDP), which was initiated by the Government of Ukraine, and it is a continuation of RSIP I and RSIP II. The project activity will be conducted at the selected sections of the M-03 highway from Poltava to Kharkiv, where the pilot area for the first group of measures, that directly reduce fragmentation by providing links between habitats severed by the infrastructure, was chosen.

The highway under reconstruction crosses the elements of the Consolidated Draft Scheme for National Eco-network of Ukraine between 341 and $472 \mathrm{~km}$. These are the Galitsko-Slobozhanskyi natural latitudinal corridor in Khar- 
kiv oblast and the Vorskla regional eco-corridor in Poltava oblast.

The main components of the Poltava regional eco-network scheme are 9 local and 3 regional wildlife corridors Vorsklianskyi, Psilskyi, Sulynskyi, which are connected in the south with the national Dniprovskyi natural corridor, and intersect in the central part with the Galitsko-Slobozhanskyi natural latitudinal corridor, along which the natural nuclei with the key territories are located.

The ecosystems of the Vorsklianskyi eco-corridor are a home for 152 species of rare plants $(70 \%$ of the total number of regional rarities, including the largest number of species of zonal vegetation), Psilskyi - 124 species, and Sulynskyi -49 .

The regional eco-network scheme of the Kharkiv region consists of 7 local wildlife corridors and 3 spatial structures of national importance: Pridonetsk eco-region and two ecocorridors (Galitsko-Slobozhanskyi and Siversko-Donetskyi).

The eco-corridor provides protection for 73 species of plants and fungi and 63 species of animals from the Red Book of Ukraine, which, respectively, makes up 13.5 and $16.5 \%$ of their total quantity, including 60 vascular plants, 1 lichen, 2 fungi, 10 mammals, 25 birds, 1 fish, 22 insects and 5 species from other systematic groups.

The project of habitat fragmentation mitigation at the pilot area. Fauna passages and modifications to infrastructure that enhance the possibility of safe animal movements are the most important measures for mitigating habitat fragmentation at the level of a particular infrastructure. Five sites in need for appropriate wildlife crossing structures were chosen at the pilot area.

Point 1 - Kharkiv oblast, between villages Pasichne, Zolochivske, Butsivka, Cheremushne was chosen because the pilot road section crosses latitudinal eco-corridor of national importance. After the analysis of terrain and target species the landscape bridge was defined to be the most appropriate. Landscape bridges are the largest wildlife crossing structures that span highways. They are primarily intended to meet the movement needs of a broad spectrum of wildlife from large mammals to reptiles, and even invertebrate taxa. These structures are designed exclusively for the use of wildlife, prohibiting human use and human-related activities adjacent.

Dimensions: minimal bridge width is $70 \mathrm{~m}$; recommended $>80 \mathrm{~m}$; fence/ embankment height is $2.4 \mathrm{~m}$; soil depth is 1.5-2.0 m. Types of construction: span - bridge span (steel truss or concrete), arch - pre-fabricated cast-in-place concrete arches, corrugated steel.

Crossing Structure: Landscape bridges should be a heterogeneous environment, combining open areas with arboreal plantations: trees and dense shrubs should be planted on edges of structure to provide cover and refuge for smalland medium-sized wildlife, the center section of overpass should be left open with low-lying or herbaceous vegetation. Local topography should be created on surface with slight depressions and mounding of extracted material, some of depressions must be covered with impermeable substrates to hold water from rainfall. Site and environmental conditions (climate) require drought-tolerant species of plants. Embankment and walls of dense vegetation will also play the role of sound- and light-attenuating walls on the sides of the structure. The walls should extend to approach ramps and curve around to wildlife exclusion fence.
Model target species are:

- Spermophilus suslicus (nature conservation status: disappearing - the Red Book of Ukraine; species whose state is close to a threatening - the IUCN Red List; species that needs special protection - the Bern Convention);

- Elaphe dione (nature conservation status: disappearing - the Red Book of Ukraine);

- Desmana moschata (nature conservation status: disappearingthe Red Book of Ukraine; vulnerable species - the IUCN Red List and the European Red List; endangered species - the Bern Convention (Annex II));

- Grus grus (Rare - the Red Book of Ukraine; protected by CITES (Annex II), Bern Convention (Annex II), Bonn Convention (Annex II), AEWA agreement).

Point 2 - The WBO Project foresees reconstruction of the Vorskla Bridge, so at this point mitigation measures do not require any specific construction just modifying embankments under the bridge to provide permeability for animals. Thus, viaduct/river crossing with support pillars help keep habitats intact and nearly undisturbed, as well as restore or maintain hydrological flows and the biological diversity associated with riparian habitats. They are multi-purpose structures: intended for wildlife, but may support occasional human use.

Dimensions: the project foresees a capital repair of the Vorskla bridge crossing $224.94 \mathrm{~m}$ wide, so the corresponding area will become a wildlife crossing after modification of embankments under the bridge. Types of construction: concrete bridge span with support structures, steel beam span.

Crossing structure: Areas under the bridge should be restored after construction with the same vegetation and conservation of local landform. Stringers of brush, root wads, rows of tree stumps, heaps of twigs or stones can provide cover for small vertebrates and act as a link between bushes or hedges on either side of the bridge. Pillars should avoid impacting riparian habitats completely, being outside the high-water mark.

Model target species are:

- Neomys anomalus (nature conservation status: rare - the Red Book of Ukraine, listed in the IUCN Red List; species that need protection - the Bern Convention);

- Lutra lutra (Nature conservation status: invaluable - the Red Book of Ukraine; species whose state is close to the threatening - the IUCN Red List; listed in the CITES list (Annex I); species to be specially protected - the Bern Convention).

Point 3 - Kharkiv oblast, Kalenikove village, - it is the crossing of pilot road section with migratory road of small and medium sized mammals. The most appropriate structure for this point is joint-use underpass. It includes direct use of bridge for transport and provides continuous permeability for animals.

These underpass structures are frequently used by several large mammal species, if they are adapted for their specific crossing requirements. Small- and medium-sized mammals (including carnivores) generally utilize these structures, particularly if riparian habitat is retained or cover is provided along walls of the underpass by using logs, brush or root wads. These underpass structures can be adapted for amphibians, semi-aquatic and semi-arboreal species.

Dimensions: minimal width is $2 \mathrm{~m}$; recommended is $>3 \mathrm{~m}$; minimal height is $3 \mathrm{~m}$; recommended is $>4 \mathrm{~m}$. Types of construction: concrete bridge span (open span bridge), steel beam span, concrete bottomless arch. 
Crossing structure: Underpass structure should span the portion of the active channel migration corridor of unconfined streams needed to restore floodplain, channel and riparian functions. It should be designed to conform to local topography, prevent flooding within underpass and run-off from the highway.

Model target species are:

- Sicista subtilis (nature conservation status: disappearing - the Red Book of Ukraine; listed in the IUCN Red List and the Bern Convention (Annex II)).

- Lutra lutra (nature conservation status: see above).

Point 4 - the Poltava oblast, between Vasylivka and Zelenkivka villages - it was chosen due to clearly defined routes of model target species \& high species diversity. For such locations small underpass is the best option. The underpass should be placed as close as possible to the site, where the path crosses the infrastructure.

Dimensions: diameter is $1-2 \mathrm{~m}$, length is $5-10 \mathrm{~m}$. Types of construction: concrete bottomless arch, circular multiplate metal culvert, or prefabricated concrete box culvert.

Crossing structure: It must maximize microhabitat complexity and cover within underpass using salvage materials (logs, root wads, rock piles, etc.) for sustained use by semi-arboreal mammals, small mammals, reptiles and species associated with rocky habitats. The tunnel should be accessible for inspection. Access for animals to the underpass has to be unobstructed. Fences are necessary for 25$50 \mathrm{~m}$ on either side, but tunnel entrances have to be placed outside any fences, which run alongside the transport infrastructure.

Model target species are:

- Mustela eversmanni (nature conservation status: disappearing the Red Book of Ukraine; listed in the IUCN Red List and the Bern Convention (Annex II)).

- Ellobius talpinus (Nature conservation status: disappearing - the Red Book of Ukraine; listed in the IUCN Red List).

Point 5 - Kharkiv oblast, Snizhkiv village - multi-use overpass may be used by pedestrian and animals simultaneously and this was chosen for this location. Insectivore species have an important nature conservation status for ecosystem, so their spread should be encouraged here.

Design of the structure is similar to a wildlife overpass; however it is generally narrower than a wildlife overpass, but still adequate for movement of large mammals. Smalland medium-sized mammals will utilize these structures, particularly generalist species common in human-dominated environments. Structures may be adapted for semi-arboreal species. Semi-aquatic and amphibian species may use them if they are located within their preferred habitats.

Dimensions: minimal width is $10 \mathrm{~m}$, recommended is $15-25 \mathrm{~m}$; fence/berm height is $2.4 \mathrm{~m}$; minimal height of wall is $2.5 \mathrm{~m}$; soil depth is $0.5-1.0 \mathrm{~m}$.

Types of construction: span - bridge span (steel truss or concrete); arch - pre-fabricated cast-in-place concrete arches, corrugated steel.

Crossing structure: If the structure has a one-lane road, the lane may be paved or gravel, but sides should be vegetated with grasses or shrubs. The same is true if the lane is a trail for hiking or horseback riding. Borders or other separations (e.g., curbs) should not be installed at interface between human-use line and wildlife pathway, instead the interface between the two should be as natural as possible and without obstacles of any kind.

Model target species are:
- Neomys anomalus (nature conservation status: see above);

- Desmana moschata (nature conservation status: see above).

So, the developed scheme of wildlife crossings is complex, depending on the specific conditions of each location, but there are some important issues in common: maximal application of native soils adjacent to and within the crossing, elimination of any human use, that activity or potential disturb the animals within the structure, and conformity to the local topography. However, its successful implementation is based on efficient habitat management and maintenance of crossing structure. Thus, each wildlife crossing must be monitored on regular basis, and periodic visits should be made to ensure that there are no obstacles or foreign matter in or near the pass that might affect wildlife use. Fences should also be checked, maintained and repaired periodically (minimum once per year, preferably twice per year).

Conclusions. Significant effects of transport network operation on components of the environment are especially important in relation to the habitats integrity and populations stability. Transport infrastructure impacts include direct effects, like loss of habitats, barrier and edge effects, bruising and injuring of fauna, disturbances of tranquility and pollution, and secondary ones, such as the emergence of settlements or industrial objects, which interact and increase their negative impact through synergy.

The comparative analysis of the measures to protect wildlife along transport infrastructure and to reduce habitat fragmentation at the pilot area, namely the road M-03 between Poltava and Kharkiv within the range from 341 to $472 \mathrm{~km}$, was conducted using ecosystem approach. The sites for location of wildlife mobility structures were chosen at the contact points between the road and the GalytskoSlobozhansky natural latitudinal and the Vorskla regional eco-corridors, which are integral parts of the eco-network. The proposed structures include landscape bridge, viaduct/river crossing, joint-use underpass, underpass for small- and medium-sized animals, and multi-use overpass. To substantiate the need for the creation of wildlife crossings the model target species were chosen, their conservation importance at a local, regional, national and international scale was determined.

The success of balanced development of transport and ecological network is based on a variety of factors to be accounted: planning of transport corridors and their integration in the landscape (types of passages, target species, density of passages, location of passages, integration into the surroundings), implementation of state monitoring system of ecological network, integration of regional and local ecological networks in the national eco-network of Ukraine. Also, fauna passages and other structures adapted to increase the crossing of transport infrastructure by animals should never be considered in isolation. They should be part of a general 'permeability concept' in the infrastructure projects.

\section{Перелік використаних джерел}

Beier, P., Majka, D., \& Jenness, J. (2007). Conceptual steps for designing wildlife corridors. Northern Arizona University.

Beier, P., Majka, D., Newell, S., \& Garding, E. (2008). Best Management Practices for Wildlife Corridors. Northern Arizona University.

Benítez-López, A., Alkemade, R., \& Verweij, P. A. (2010). The impacts of roads and other infrastructure on mammal and bird populations. Biological Conservation, 143(6), 1307-1316. https://doi.org/10.1016/j.biocon.2010.02.009. 
Bennett, G. (2004). Integrating biodiversity conservation and sustainable use. Lessons learned from ecological networks. IUCN Gland, Switzerland and Cambridge, UK.

Crooks, K. R., \& Sanjayan, M. (2006). Connectivity conservation. Cambridge, UK: Cambridge University Press. https://doi.org/10.1017/CBO9780511754821.

Damarad, T., \& Bekker, G. J. (2003). COST 341- Habitat Fragmentation due to Transportation Infrastructure: Findings of the COST Action 341. Luxembourg: Office for official publications of the European Communities.

Donovan, T. M., Lamberson, R. H., Kimber, A., Thompson, F. R., \& Faaborg, J. (1995). Modelling effects of habitat fragmentation on source and sink demography of neotropical migrant birds. Conservation Biology, 9(6), 1396-1407. https://doi.org/10.1046/j.1523-1739.1995.09061396.x

Fahrig, L, \& Rytwinski, T. (2009). Effects of roads on animal abundance: an empirical review and synthesis. Ecology and Society, $14,21-41$.
Forman, R. T. T., Sperling, D., Bissonette, J. A., Clevenger, A. P., Cutshall, C. D., Dale, V. H., Fahrig, L., France, R. L., Goldman, C. R., \& Heanue, K. (2002). Road Ecology: Science and Solutions. Island Press. https://doi.org/10.1002/ep.670220307

Hunter, M. L. (1996). Fundamentals of Conservation Biology. Cambridge, Massachusetts: Blackwell Science.

Kozak, J., et al. (Eds.). (2013) The Carpathians: Integrating Nature and Society Towards Sustainability, Environmental Science and Engineering, Springer-Verlag Berlin Heidelberg. https://doi.org/10.1007/978-3-642-12725-0 49

Reijnen, R., Foppen, R., \& Veenbaas, G. (1997). Disturbance by traffic of breeding birds: Evaluation of the effect and considerations in planning and managing road corridors. Biodiversity and Conservation, 6, 567-581.

Sawaya, M. A., Clevenger, A. P., \& Kalinowski, S. T. (2013). Demographic connectivity for ursid populations at wildlife crossing structures in Banff National Park. Conservation Biology, 27, 72130. https://doi.org/10.1111/cobi.12075

М. М. Радомська, К. В. Журбас

Наиіональний авіаційний університет, м. Київ, Украӥна

\section{ПРАКТИЧНІ АСПЕКТИ ЗМЕНШЕННЯ ФРАГМЕНТАЦІЇ АРЕАЛІВ ТВАРИН ДЛЯ ПРОЕКТІВ УДОСКОНАЛЕННЯ ІНФРАСТРУКТУРИ}

Розглянуто негативні впливи транспортної мережі на живі організми в зоні їі розташування. Зазначено, що дороги порушують цілісність ареалів тварин, створюючи перешкоди на шляху їх міграції, руху у пошуках їжі, притулку або репродуктивної поведінки. Явище фрагментації ареалів розглянуто з погляду не лише розділення території на окремі недоступні елементи, а і скорочення загальної площі середовища існування, зміни співвідношення площі ядра ареалу та площі його меж, де розвивається крайовий ефект. Показано, що порушення цілісності території проживання тварин порушує їх нормальну життєдіяльність і спокій через шум, освітлення та забруднення від транспорту, а також збільшує випадки зіткнення диких тварин і транспортних засобів, призводить до генетичної ізоляції, чим створює для деяких видів довготерміновий ризик вимирання. Для зменшення негативних впливів автостради проаналізовано пілотну ділянку на шосе М-03 від Полтави до Харкова в межах від 341 до 472 км, що підлягає реконструкції за проектом Світового банку. На території було виділено п'ять ділянок, де потрібно забезпечити мобільність представників дикої природи за допомогою спеціальних переходів різних типів: міст, річковий перехід, підземний перехід спільного використання, підземний перехід для малих і середніх тварин та багатоцільовий шляхопровід. Для кожного об'єкта розроблено рекомендації щодо дизайну, будівельних конструкцій і матеріалів, а також визначено цільові види тварин-користувачів та їх природоохоронний статус.

Ключові слова: збереження біорізноманіття; екологічна мережа; екологічні коридори; мобільність диких тварин; екодук.

М. М. Радомская, К. В. Журбас

Национальный авиаџионный университет, г. Киев, Украина

\section{ПРАКТИЧЕСКИЕ АСПЕКТЫ УМЕНЫШЕНИЯ ФРАГМЕНТАЦИИ АРЕАЛОВ ЖИВОТНЫХ ДЛЯ ПРОЕКТОВ УСОВЕРШЕНСТВОВАНИЯ ИНФРАСТРУКТУРЫ}

Рассмотрено негативное влияние транспортной сети на живые организмы в зоне ее расположения. Отмечено, что дороги нарушают целостность ареалов животных, создавая препятствия на пути их миграции, движения в поисках пищи, убежища или репродуктивного поведения. Явление фрагментации ареалов рассмотрено с точки зрения не только разделения территории на отдельные недоступные элементы, а и сокращения общей площади среды обитания, изменения соотношения площади ядра ареала и площади его границ, где развивается краевой эффект. Показано, что нарушение целостности территории обитания животных нарушает их нормальную жизнедеятельность и покой из-за шума, освещения и загрязнения от транспорта, а также увеличивает случаи столкновения диких животных и транспортных средств, приводит к генетической изоляции, чем создает для некоторых видов долгосрочный риск вымирания. Для уменьшения негативных воздействий автострады проанализирован пилотный участок на шоссе М-03 от Полтавы до Харькова в пределах от 341 до 472 км, подлежащего реконструкции по проекту Всемирного банка. На данной территории было выделено пять участков, где необходимо обеспечить мобильность представителей дикой природы с помощью специальных переходов разных типов: мост, речной переход, подземный переход совместного использования, подземный переход для малых и средних животных и многоцелевой путепровод. Для каждого объекта разработаны рекомендации по дизайну, строительным конструкциям и материалам, а также определены целевые виды животных-пользователей и их природоохранный статус.

Ключевые слова: сохранение биоразнообразия; экологическая сеть; экологические коридоры; мобильность диких животных; экодук. 